\title{
Non habemus papam - the Abdication of Benedict XVI as Depicted in Polish Realisations of the Big Picture Report (Genealogical Contexts)
}

The conventional division into informational and publicistic thinking is progressively being relegated to a secondary position in modern journalism. In the circumstances of an excess of news, its superficial absorption, the demand for perceptual and interpretative simplification of interacting with the very fast influx of media messages, it should be expected to evolve in the direction of hybrid forms, even remaining at the stage of permanent "forming", and potency, which may be realized at any moment and in a shape that is currently in demand.

The highest number of examples indicating this tendency may be found in the newest medium, closest to the universal ideal, namely the Internet. It appears that interesting research perspectives result from the attempt to investigate generic realizations of the so-called big picture report, a journalistic form which is widely represented on the Internet. The initial assessment of materials identified by this name shows that it is very often "exaggerated", and the effects of editing works on such a "report" have little in common with its genealogical characterization. It is worth examining this on the basis of big pictures devoted to the abdication of Pope Benedict XVI.

First of all, it should be observed that this event suits the requirements of a news item, understood as a message about a fact, which is characterized by a high informative value ${ }^{1}$. Adopting seven factors of information described by Marek Chyliński and Stephan Russ-Mohl ${ }^{2}$ as points of reference, the news of Joseph Ratzinger's decision and its consequences may be characterized in the following way:

* Dr hab., e-mail: mowors@uni.lodz.pl; University of Lodz, Faculty of Philology, Department of Journalism and Public Communication; ul. Pomorska 171/173, 90-236 Łódź.

${ }^{1}$ See: M. Palczewski, „Ontologiczne modele newsa. Zarys problematyki”, Studia Medioznawcze 2010, No. 2, p. 147.

${ }^{2}$ See:. M. Chyliński, S. Russ-Mohl, „Dziennikarstwo”, Grupa Wydawnicza Polskapresse, Warsaw 2007, pp. 120-131. 
The event had a clearly defined initial moment (12 ${ }^{\text {th }}$ February in the morning) and a moment of closure, which involved two different points in time: the end of the pontificate $\left(28^{\text {th }}\right.$ February, $\left.8.00 \mathrm{pm}\right)$ and the day of the selection of the new Pope (the end of the conclave predicted for the time preceding the liturgy of the Holy Week). The temporal horizon of the event was therefore restricted, yet at the same time made it possible to maintain continuity - the decision to resign evoked relatively recent (2005) memories of the last vacancy in the position of the bishop of Rome.

The geographical and political distance did not make it difficult to understand the ongoing events, because they were close to the Polish recipient. The most important role, however, was played by cultural proximity connected with the religious aspect of the event, and additionally stressed by the direct relationship between the main character and the Polish Pope John Paul II.

The high profile of the figure at the centre of attention, and in some cases also of the background characters (commentators such as Cardinal Stanisław Dziwisz, Archbishop Józef Kowalczyk; participants such as Cardinal Angelo Sodano, Cardinal Camerlengo Tarcisio Bertone, Vatican spokesman Father Federico Lombardi, clergymen from the circle of the papabile), favoured the interest in the matter of the abdication. The newsworthiness of the subject was also increased by the fact that the person and position of the Holy Father is associated with traditional and sacral understanding of the power elite (aristocracy, royal families, bloodline) rather than with democratic procedures (tenure of presidents and prime ministers) ${ }^{3}$.

The information regarding Benedict XVI's resignation, unannounced in any, even unofficial, way, appeared suddenly, and immediately dominated the news. The surprise caused intense curiosity, and the atypical nature of the act that was about to occur opened a space for speculations, inquiries and comparisons, which could arouse the willingness to participate in the ongoing events through the media. After an initial, relatively short, period when journalists were chaotically identifying the subject, it turned out that the changes initiated by the Pope's announcement will proceed in an organized and largely predictable manner, which simplified the structure of the event (limited number of participants and accounts connecting different facts). The pace of narration in the media became distinctly less intense as early as on the third day, and the subsequent culmination of events took place according to the schedule, which was dictated by the procedure of selecting the new bishop of Rome (the last Angelus prayer and the last general audience with Benedict XVI, the last day of the pontificate, inauguration and closure of the conclave).

\footnotetext{
${ }^{3}$ These associations resulted largely from - as one may think - the language of information and comments, which often employed expressions and phrases such as: "abdication", "Throne of Saint Peter", "Saint Peter of our times", "ministry", "«interregnum» in Vatican", "the need for holiness". The iconic aspect of messages was also significant, as it illustrated contents with images of antique interiors and buildings, exceptionally ornamental attire, ceremony and courtly rituals.
} 
The announcement of the Pope's decision to abdicate launched a discussion about the significance of this act for the Catholic Church and the community of believers, which indicated an ambivalent attitude towards the behaviour of Benedict XVI. It appears, however, that this ambiguity did not diminish the informative value of the news in this case. The unusual nature of the event induced the audience to familiarize themselves with the opinions of people who were better acquainted with the problem, such as clergymen and journalists specializing in religious topics - when asked to comment, they clearly formulated judgements, on the basis of which, recipients could categorize the event as either positive or negative.

The analysed event drew the attention of recipients to the man - admittedly a person of advanced age, but holding an exceptional position. The decision of Benedict XVI, justified by his lack of sufficient strength to perform the duties of the head of the Church, emphasized the human aspect of the papal office, enabling the recipients to strongly identify. Emotional engagement, and even a certain sentiment evoked by the memories of John Paul II's passing, gave the story a somewhat tabloid character and made its adoption easier.

Thanks to the high personalization of the event and the elitism of the main character, the visual aspect of Benedict XVI's resignation also increased the informative value of the news. In big pictures it was expressed by complementing and sometimes replacing the written content with photo galleries and audio-video sequences.

The "newsness" of the sequence of events initiated by the Holy Father's decision, and ended by the deliberations of cardinal electors during the conclave corresponded, in my opinion, to the specific formula of the genre known as the big picture report. Competently practised, it allows the creation of an original, multilayered story, in which diverse media materials comprise an authorial depiction of an event. Its creator may also demonstrate creativity, using the opportunities offered by convergence, hypertextuality and the communicativeness of the internet. At the same time, the report becomes a source, a library at hand, and an archive gathering organised knowledge of a given subject, which the user of the internet may learn according to the algorithm designed by the author or in an arbitrary way, characteristic of free surfing. This perspective differs substantially from Leszek Olszański's attitude to the genre, because it emphasizes the importance of organizing the materials in a correct way, which contributes to coherence and clarity. The author of Media i dziennikarstwo internetowe (eng. Internet media and journalism), on the other hand, observes that:

At first glance, the big picture report may be associated with [...] a multimedia article. However, this is only a partial similarity. A multimedia article constitutes a wellthought-out entirety, in which elements realized in different techniques are selected and edited in such a way as to create a joint, coherent narration. A big picture is 
closer to a monographic, yet lively, information service, created ad hoc from available materials and developed as more news, opinions and analyses come. Referring to analogies in the press, it may be claimed that a multimedia report [sic!] is a richly illustrated article. A big picture is more of an insert devoted to a given subject provided with a general information edition of a newspaper, which can be constantly expanded with new texts, photographs and multimedia ${ }^{4}$.

According to Olszański, the aforementioned correct organization, which manifests itself in the selection and above-standard editing of materials, is more characteristic of a multimedia article. In my view, if a big picture lacked such organization, it would be too close to a simple, thematic collection (collections) of hyperlinks, in the creation of which the requirement of coherence is treated arbitrarily, there is no hierarchization, and the only organizational criterion is topicality $^{5}$. Such a genealogically unspecified composition may constitute "a lively information service, created ad hoc from available materials". A multimedia article would be the opposite of this, in which the most important text is surrounded by clearly selected and hierarchized materials, which complement and elaborate on the chosen subjects. A big picutre should be placed between the listed "journalistic metaworks" (Olszański's term) - its value would consist in the wealth and diversity of multimedia content, subjected, however, to authorial control; for example, by clear segregation of themes, correction of errors, deletion of outdated materials, modification of those already published or rejection of those which do not contribute with important details. Such a report would constitute a coherent, narratively organized entirety, in which the moment when it is no longer updated may be accurately defined. It would also require a more critical and creative approach from the author towards the journalist's task rather than merely "creating a rich compendium of knowledge with relatively simple methods"6.

Being conscious of the fact that the internet as a medium is still being shaped -completing the traditional order of: press, radio, television - it is worth asking what an analysis of content conducted on material whose "newsness" corresponds

${ }^{4}$ L. Olszański, „Media i dziennikarstwo internetowe”, Wydawnictwa Akademickie i Profesjonalne, Warsaw 2012, p. 134.

${ }^{5} \mathrm{Cf}$. collections of links concerning the abdication of Benedict XVI: http://tematy.newsweek. pl/temat/abdykacja_benedykt; http://tvp.info/informacje/raporty/abdykacja-benedykta-xvi; http:// wiadomosci.onet.pl/tagi/papiez-benedykt-xvi-abdykuje,73699,tag.html [access: 5.03.2013].

${ }^{6}$ Cf. L. Olszański, „Media”, op. cit., p. 134. The author also notices the evolutionary relationship between the big picture and the multimedia article, describing what may be done with materials gathered for the needs of an article, when their number approaches "critical value": "If the importance of the event and the interest of the audience justifies it, the editorial team may edit and rewrite the existing documentation into a real, thought out and creatively composed multimedia article [...]. The lifespan of a multimedia article should be even longer than in the case of an archival version of a big picture" (ibid., pp. 139-140). 
so well to the specificity of the communicational requirements of the internet could say about the genealogical nature of the big picture report. Does its position between a simple catalogue of equivalent hyperlinks and a centrically designed and hierarchically organized multimedia article allow the genre to evolve and if so, in which direction? And finally - do the researched realizations of the genre constitute valuable examples of the work of internet editors? This is an attempt to answer that question.

A preliminary study of the contents of the leading Polish general information portals, as well as websites of prominent press titles and radio and TV stations, revealed that the universal interest in the subject of the Pope's resignation was almost unexpressed in the way big pictures were edited. Only a few were created ${ }^{7}$ (on the websites of Interia, Wirtualna Polska, RMF FM radio ${ }^{8}$ and Rzeczpospolita daily $^{9}$ ), whereas the majority of editorial teams limited themselves to tagging published materials in such a way that clicking on a key word (e.g. "Benedict XVI", "Pope's abdication", "conclave") opened a list of links organized chronologically from the most recent. Unlike in the case of reports, it was not categorized but included insufficiently selected links to outdated articles or ones loosely connected with the person of Benedict XVI or the business of the Vatican.

From the perspective of genre determinants, the aforementioned big pictures resemble each other in a number of respects.

First of all, they use a similar structure, which comprises a dominant element in the form of a list of hyperlinks with the latest news, and a few links to sub-pages gathering other materials concerning the abdication of the Pope, such as: "Opinions", "Pope and Poland", "Who will be next after Benedict XVI", "Witness accounts", "Gallery". The report on the web page of Rzeczpospolita is an exception; it features a collection of the newest publications under the headline Benedict XVI abdicates and three overlapping tabs next to it, with links grouped as: "Most read", "Last minute", "Highest rating". Hyperlinks in the form of headlines refer to particular texts, which are already present on the list of latest news. The report should be assessed as structurally flawed; it does not offer any supplementary materials (weakened scanning effect - the ability to easily follow the

\footnotetext{
${ }^{7}$ They were chosen for the analysis because they include elements characteristic of the genre and were tagged as "Report" by their editorial team (in the case of Interia and WP - "Special report"). The material on TVP Info's website, even though it was published in the section "Reports", was rejected since it constitutes a simple collection of links (every hyperlink includes a miniature of a photograph, date and hour of publication, a headline and 2-3 sentences of lead).

${ }^{8}$ The website with RMF FM's report (entitled "Abdication of Pope Benedict XVI") on the Pope's resignation was deleted on $10^{\text {th }}$ March 2013. A new report appeared, namely "The choice of the new Pope", in which one of the sub-pages entitled "Benedict XVI's resignation" includes a collection of news from the deleted report.

${ }^{9}$ Rzeczpospolita's report (entitled "Benedict XVI abdicates") stopped being updated on $11^{\text {th }}$ March 2013. Part of the materials it contained was included in the report entitled "Conclave".
} 
course of events), is functionally orientated towards notifying and emphasizes the social dimension of using internet publications.

Secondly, the latest news sections of the different big pictures are nearly identical because the vast majority of current information was copied from the dispatches of the Polish Press Agency. This may significantly affect the image of the event that emerges from reading them - it will be similar in every case, since the journalistic concept of presenting the subject must include a large quantity of unique materials, a well-thought-out and dynamic composition and must exhibit the fundamental components of a report to be original.

The publicistic approach is a secondary feature in the analysed reports. It mostly manifests itself in quoting opinions taken from other messages (statements of Church hierarchs made during briefings for journalists, texts mainly from the Italian and German press), but is rarely demonstrated in publications whose dominant function is that of shaping views, such as commentaries, interviews, editorials, and some types of profiles. Even though special sections were distinguished in Interia's and RMF FM's big pictures, it should be acknowledged that they temporarily organize the inflow of materials, and editors are more concerned with the emotional and axiological expressiveness of titles and previews/leads $[16]^{10}$ rather than with presenting coherent and well justified beliefs.

Thirdly, the sub-pages which expand the choice of news are usually based on a template and unfinished. Materials gathered here often appear as the most recent information and are later moved to other tabs, e.g. those including opinions or photographs. It seems that their only organizational criteria are: the form (textuality vs. iconicity) and the profile of the publication, which manifests itself in its purpose or subject (e.g. tabs "Opinions", "Pope and Poland", "Papabile" in Interia's report). In this case, the agency dispatches are the most important source of information as well; RMF FM's report should therefore be appreciated, as it contained the tab "Coverage of special correspondents for RMF FM", which featured original reports from the radio station's journalists ${ }^{11}$. In terms of quantity, the content of sub-pages is incomparable - it ranges from one extensive text (e.g. a conversation with a sociologist of religion, Paweł Załęcki, in the tab "According to experts [sic]" in WP's report) to about ten (e.g. the tab "Conclave" in Interia's report). On the web page with a text (photos), there are also hyperlinks to other materials concerning the abdication of Benedict XVI, which allow the user to freely navigate through different publications and tabs.

${ }^{10}$ This labelling refers to the publications listed in the bibliography. E.g. lead: "«Karol Wojtyła damaged the Church, turning the institution into a one-man show»- Tim Parks writes about John Paul II in the American edition of «Newsweek». In his view, «Ratzinger, in a single gesture, has done more for the church and the papacy than Wojtyła ever did»" [3].

${ }^{11}$ Editorial materials in Rzeczpospolita's report are also distinctly original, yet they were not distinguished as sub-pages. 
The lack of sections supporting interactivity (e.g. forums, surveys, other users' materials), gathering visual and educational contents (e.g. infographics, comparisons, calendars) or of the human story type (e.g. accounts of witnesses) is noteworthy. In the researched reports they only occur as rare, single publications [15], [39], among which the most original is the playful juxtaposition of candidates for papal succession, grouped into a football "Vatican Champions League"12.

Fourthly, in the initial period of high interest in the Pope's decision, the editorial teams were inclined to publish materials of very low informative value as long as they seemed topical ${ }^{13}$; they continued the subject later, publishing reports about insignificant details of the event ${ }^{14}$, loosely connected with $i t^{15}$, or mere trivia $^{16}$. The elements of reports were neither selected nor sorted systematically in the editing process, which clearly indicates that a big picture's task is, above all, to satisfy readers' curiosity with current news. The insufficient organization of the report's elements may, however, discourage recipients, particularly in the later period of following the events ${ }^{17}$.

In the fifth place, graphic designs of home pages of analysed reports are structured on the basis of a conventional pattern, in which the top side of the page includes a headline and tabs for sub-pages, below on the left there is a list of links to the latest news (a photo/photos, text's headline, or one or two initial sentences of a preview or the beginning of a lead, date, hour and occasionally the source of information), and complementing materials, which constitute an informational

${ }^{12}$ RMF FM's report informed about the idea of the Stacja7.pl portal, and at the same time offered users the chance to take part in a contest with book prizes (selecting a candidate on the basis of a short characterization). See: [44].

${ }^{13}$ One of the first texts in Interia's report, published after the Pope's decision had been announced, informed that: "[lead:] The news about Benedict XVI's decision to resign and end his ministry caused a great stir among the Romans and believers from all around the world who were at St. Peter's Square and in the Vatican basilica. People are sharing the news with disbelief. [body:] Thousands of people in the Vatican are baffled. Everyone wants to know if the Pope is seriously ill. The questions as to what happened are being asked in all languages. At the same time, more and more people are gathering in St. Peter's Square in order to get some information about Benedict XVI's resignation" [32]. The quality of publications in RMF FM's big picture was certainly affected by the fact that the radio station's correspondents could not reach Rome until the evening of the day when the decision was announced. Therefore, it is not surprising that their initial materials were "about nothing": Vatican at night (photos), the morning in the Vatican, accounts of first conversations with passers-by and shopkeepers, the first lights in papal apartments.

${ }^{14}$ This tendency was noticeable in all media, including the foreign ones. See: e.g., the information in WP's report about the new job of the former papal butler, who was convicted of stealing secret documents and pardoned by the Pope. [13]. Cf. L. Olszański, „Media”, op. cit., p. 135.

${ }^{15}$ E.g. in Rzeczpospolita's report [38].

${ }^{16}$ E.g. in Interia's report [37].

${ }^{17}$ See: L. Olszański, „Media”, op. cit., pp. 137-138. Zob. też: L. Olszański, „Dziennikarstwo internetowe", Warsaw 2006, p. 86. 
background ${ }^{18}$, are located on the right. However transparent, the structural monotony of individual hyperlinks (a photo and short text) gives a strong impression that all publications ${ }^{19}$ lack diversity in terms of form and quality. At first glance, the user may only determine the sequence in which the materials appeared on the page. Adopting such design premises clearly indicates that editors prepare reports predominantly for readers who are ready to devote more time to reading them than they normally do, interested in the subject, and willing to acquaint themselves with many details. At the same time, attributing the role of the "opening" material to a list of the latest news (the most recent publication on sub-pages) makes the visitors realize that they should repeatedly return to this page, getting to know new facts, which complement the image of the event ${ }^{20}$.

The problem of interactive connectivity between the material that is made available after clicking and other publications, which co-create the report, attracts attention. It may be minimal, as in Interia's big picture, or relatively large, though quantitatively incomparable for individual texts, as in the case of RMF FM's report. Undoubtedly, inserting too many links in a web page (as in the case of Wirtualna Polska's big picture) makes it unfriendly and chaotic, it appears, then, that their limited quantity should be compensated by quality. The materials connected by hyperlinks may be related in terms of content [8] or distinct from each other [10], which, in the case of the researched reports, probably results from the need to stimulate the popularity of particular publications ${ }^{21}$.

In the sixth place, the analysed big pictures predominantly accumulate textual materials with attached photography. The graphical element functions here as an illustration ${ }^{22}$, which limits the interpretative and evaluative significance of

${ }^{18} \mathrm{Cf}$. a more interestingly structured report on the subject of riots in Great Britain in 2011 discussed by Olszański („Media”, op. cit., pp. 136-138).

${ }^{19}$ See: e.g., the web page of Interia's report, where the link to information about the anticipated crowds in Rome after the last day of the pontificate does not differ visually from the link to the report that Cardinal Angelo Scola becomes a clear favourite before the conclave, nor from the hyperlink to the page with an interview given by professor Stanislaw Obirk [19].

${ }^{20}$ See: L. Olszański, „Media”, op. cit., pp. 137-138.

${ }^{21}$ Since only a few reports were examined, it is difficult to formulate irrefutable conclusions, but the analysed material reveals an interesting tendency - in the most extensive big picture (Wirtualna Polska's), a high number of hyperlinks, predominantly located at the bottom of the page, usually refer to publications loosely related with each other in terms of the subject, whereas the most modest report (Rzeczpospolita's) is set apart by its well-thought-out and coherent system of "linking" the texts.

${ }^{22}$ The fact that editors do not attach great significance to such photographs is proven by: attaching a picture of a Greek boy (with the following caption: "Simple, far-right slogans appeal to increasingly younger inhabitants of crisis-ravaged Greece") to the profile of Benedict XVI, which remained uncorrected [48]; frequent lack of sufficient coherence between textual and graphical elements [35]; the use of unattractive (of low quality, badly framed, not aesthetic) and repetitive photographs. 
the whole material. In the case of a collection of photographs (sometimes also a gallery), the images document the event; they may also act impressively, which is exemplified by a humorous collection presenting the Pope's struggle with the wind [6].

The use of audio and video applications in reports is connected with their availability - the researched material shows that the big pictures published on the web pages of the radio station and the daily are clearly more attractive in this respect, since their editors could use recordings prepared by their own correspondents [45], [47].

The differences between the reports in question, apart from the already mentioned crucial contribution of unique journalistic materials on RMF FM's page, chiefly consist in the dissimilarity of graphical details (e.g. in Interia's report, the most current news is additionally highlighted; on Rzeczpospolita's page, the opening material is comprised of three pieces of information composed in the form of dynamically changing tabs). The big picture of Wirtualna Polska is pale by comparison with the rest due to a higher density of materials combining text and graphical elements, and the neighbouring links which are unrelated to the topic of the abdication. Interia's report, on the other hand, in spite of graphical monotony, is distinguished by the user-friendly structure of many sections (tabs and additional materials).

More interesting differences between the analysed realizations of the genre may be spotted while focusing on their contents. If they are treated as a journalistic way of telling about ongoing events, their originality surely depends on: the presence of unique materials (particularly commentaries, editorials, columns, infographics and multimedia) and editorial works (selecting and editing the texts). As was emphasized, in this respect, Polish big pictures devoted to the papal abdication do not constitute model examples; however, it cannot be claimed that the basic elements of narration, such as stories of characters/character, their supposed intentions, complications and motivations ${ }^{23}$, were modelled in an identical manner.

The beginning of a journalistic story slightly precedes the initial stage of structuring a report - when the first opinions are added to the news about the event. In the discussed case, it was almost the very same moment, since the earliest publications, apart from the details concerning the Pope's address during the consistory (which included the justification of his decision), also contained short statements by high Church officials and Joseph Ratzinger's brother- Georg, a profile of Benedict XVI and the comments of Polish columnists and clerics ${ }^{24}$.

${ }^{23}$ Cf. J. Trzebiński, „Narracyjne konstruowanie rzeczywistości”, in: „Narracja jako sposób rozumienia świata”, ed. J. Trzebiński, Gdańskie Wydawnictwo Psychologiczne, Gdansk 2002, p. 23.

${ }^{24}$ It is difficult to establish the exact contents of the earliest pieces of information, since they could be repeatedly updated within a short period of time. It seems that the original news did not include the extensive profile of the abdicating Pope. 
The reader was immediately led to believe that the Pope's decision surprised even his closest associates; this conviction was built by repeatedly quoting the words of the Dean of the College of Cardinals, Angelo Sodano, who called it a "bolt out of the blue" 25 . At the same time, the journalistic eagerness in searching for other reasons for Benedict XVI's resignation than those revealed resulted in a crystallization of one of three main narrative themes of big pictures.

However, the readers of the analysed reports may have perceived the situation slightly differently. As they acquainted themselves with the contents of Wirtualna Polska's web page, they mostly encountered commentaries on the Pope's decision and the words he used in the statement addressed to cardinals. The declaration of Benedict XVI, who wanted to communicate "a decision of great importance for the life of the Church", was described as eccentric; that made it easier to create an atmosphere of sensationalism ${ }^{26}$, in which participation in the events - even mediated - is more important than understanding their logic. Drawing the reader's attention to the reasons for the change in the position of Bishop of Rome emphasized that this aspect of the event aroused general interest, also abroad. In materials published on Interia's web-page, the extraordinary nature of the decision and the necessity to treat it seriously, which was stressed by the quoted bishops and cardinals [12], lost its distinctiveness, because the context was developed with new themes - concerning the procedure of appointing a new Pope, the candidates for succession and the probable delay in the process of John Paul II's canonization. The big picture created on the web-page of RMF FM was more concerned with the abdicating Pope $^{27}$, in a short period of time publishing an extensive profile of him and recalling his pilgrimage to Poland in 2006. The narration was more focused on creating the image of the main character of the event, and in this context the decision to abdicate could seem less surprising to the reader, yet worthy of respect and deeper reflection. The editors of Rzeczpospolita's report used archive materials, supplementing the latest news with publicistic texts (an interview with Ratzinger from 1999 and an article from 2009) and information about Benedict's health troubles (from 2011), which were probably supposed to broaden the reader's knowledge of the Pope's views and attitudes, as well as authenticate the official reason for his resignation, though they predominantly made the story

\footnotetext{
${ }^{25}$ The information that Angelo Sodano was in the circle of three people notified by Benedict XVI about his decision several days in advance appeared as early as on $12^{\text {th }}$ March. His words may therefore be interpreted as an intentional attempt to present the Pope's decision as exceptional and autonomous. While featured in all the big pictures, this news was not repeated in other materials, unlike the words of the Dean of the College of Cardinals.

${ }^{26}$ The second item reported that: "This is the first time a situation like this has happened in 700 years. Celestine V is the only Pope who has abdicated to date. He ascended the Throne of Saint Peter in 1294". This information contained two factual errors (cf. [17]), yet it was not corrected (see: [5]). The same wrong information, though not explicitly exhibited, occurred in Interia's report.

${ }^{27}$ The gallery with Benedict XVI's pictures was already included in the fourth publication.
} 
chaotic. Dominik Zdrot's article Koniec epoki kremówkowej (Eng. The end of the cream puff age) about the end of a fictional truce between the Church and the liberal world, which occurred thanks to John Paul II's successor ${ }^{28}$, turned out to be especially bizarre in that situation (although somewhat interesting). The author predicted that attacks of the Pope's opponents would intensify, and that he would strengthen the conservative policy of the Church, which could be interpreted as incomprehensible in the context of the decision to abdicate (unprecedented in almost 600 years) and its justification. Nevertheless, the deliberations and reports in both archival and current materials shared a serious tone, while the significance of frequently quoted commentaries concerning the decision explicitly showed that Benedict XVI was aware of the responsibility ${ }^{29}$.

The journalistic search for an answer to the fundamental question "Why?" did not become an opportunity to display a creative approach to editorial work; instead, it sustained the impression of an intriguing mystery kept by the Vatican. The readers could familiarize themselves with the same comments, among others Father Federico Lombardi's, who firmly rejected the speculation that depression was the reason behind the Pope's abdication [20], or Georg Ratzinger's about his brother's undermined health ${ }^{30}$. Speculation ${ }^{31}$ appeared very quickly that the decision was affected by: Benedict XVI's health being in a worse state than was officially presented ${ }^{32}$, the disloyalty of his associates, the scandals connected with the mass leak of confidential documents from the Holy See (the so-called Vatileaks scandal), the ineffectiveness of attempts to curb the schemes in the Roman Curia and the insufficiently advanced process of repairing the Church's image in a crisis situation (divisions within the Church, the consequences of paedophile and financial scandals). All of the studied big pictures narrated this theme in a similar way, which resulted from relying on identical sources and from the fact that all of the quoted representatives of the clergy consistently rejected the possibility that there were reasons other than old age and poor physical condition, which is very

\footnotetext{
${ }^{28}$ It was dated as current, but got published for the first time on $7^{\text {th }}$ February 2009 in the „Plus Minus” supplement (Rzeczpospolita, No. 32, pp. A18-A19).

${ }^{29}$ The fact that Benedict XVI's resignation was perceived as a significant event was confirmed by a commentary included in Rzeczpospolita's report, which criticised internet jokes inspired by the Pope's decision [1].

${ }^{30}$ As early as on $21^{\text {st }}$ February Fr Federico Lombardi described the last days of the pontificate as a time of "spiritual search" and asked the journalists to "respect this atmosphere and notice the spiritual character of the event, instead of focusing on sensational speculations" [41].

${ }^{31}$ Which initially used impersonal forms, such as "it is said", "it is pointed out that", and later cited Italian media and Polish commentators.

${ }^{32}$ In this case, the information about the heart surgery which the Pope underwent "in absolute secrecy" three months earlier, was crucial. The reason behind the potential doubts as to the significance of this procedure could be the fact that the doctor in charge of the medical team, Luigi Chiariello, declined to comment on these reports, even though the surgery consisted in a standard replacement of a pacemaker (see: [43]).
} 
important in the service of the good of the Church. They clearly tried to influence the way in which Benedict XVI's decision was perceived, emphasizing the bravery, wisdom, humility and responsibility of the abdicating pope; this idea was expressed in the most direct way by the Metropolitan of Warsaw, Cardinal Kazimierz Nycz, who appealed to journalists: "If you want to help and serve the Church well in this new moment, in the following days and weeks try to, above all, respectfully show the sacred nature of the Pope's mission" [22]. This poetic mood often resembled the solemnity of comments given after the death of a person who had enjoyed general affection; for example, the Archbishop of Canterbury, Justin Welby, accepted the news of the Pope's abdication with a "heavy heart" and added that he "thanks God for Benedict XVI's life" [2] $]^{33}$. As a consequence, both including descriptions of media speculation in reports and giving accounts of the official addresses of representatives of the clergy and those close to the Church, thanks to their appropriate selection and editing of the headlines and leads, could evoke a slightly lower (as in Rzeczpospolita's big picture) or greater (as on web pages of Wirtualna Polska) impression of sensationalism in the background of the events, but it did not affect the image of the "Vatican news" in a diversifying way.

In this respect, the most important role should be attributed to the ways of creating the second of the previously mentioned narrative themes, that is the evaluation of Benedict XVI's pontificate and the man himself. The first attempts took place as early as a few dozen minutes after announcing the decision to resign, while more extensive materials were published on the fourth and fifth days; the discussions summarizing this subject accompanied the end of the papal ministry on $28^{\text {th }}$ February. A division was immediately outlined - opinions of representatives of the Church and journalists close to it emphasized the difficult nature of the pontificate, the achievements and doctrinal consistency of Benedict XVI's actions [7], [33]; critics enumerated negligence, indolence and excessive departure from matters important to believers [31], [40]. It is telling that the typical opinion-forming texts (commentaries, articles, conversations) form a small group, whereas the majority of judgements expressed expressis verbis are limited to short

\footnotetext{
${ }^{33}$ This similarity appears to be understandable in the face of the fact that this was the first abdication of a Holy Father in a few hundred years. Cardinal Zenon Grocholewski described the initial reactions of clerics participating in the Consistory, during which Benedict XVI announced the abdication: "At first - surprise, but, after a moment, also understanding and conviction that this is an act of the Holy Father's bravery. And conviction that this decision must have been made with a sense of some tremendous responsibility, after thinking it over, praying it over in the spirit of faith, in the spirit of the good of the Church. We were describing it in this way, although all of us with a certain measure of sadness. We were sorry for the Pope, because it was a great Pope, a very, very open-minded man, very humble, very simple - contrary to what was sometimes said about him, that he was a sort of "panzer Ratzinger»" [21].
} 
statements given as part of interviews ${ }^{34}$. The modest content of the "Opinie" (eng. "Opinions") tab in Interia's report attracts particular attention, as it is dominated by assessments of the decision to abdicate and predictions, as well as expectations regarding the results of the conclave and tasks facing the new Pope, which clearly better correspond to the demand for "newsness". The readers of RFM FM's big picture could learn more about the pontificate; it often reported voices of criticism, but also included a more measured summary of Benedict XVI's achievements [9]. It presents the abdicating Pope as a man who maintains a spiritual bond with John Paul II, who is open and friendly but also uses an overly "hermetic" language when addressing believers. The memory of Benedict XVI's pilgrimage to Poland and the visit to the concentration camp at Oświęcim is complemented by descriptions of his controversial decisions and statements. The text, which clearly recapitulates some of the materials already included in the report, constitutes useful reading material and contributes to organizing the big picture.

The opinion-forming value in terms of the theme in question may be more extensively attributed to materials included in Rzeczpospolita's report, whose authors often interpret the actions of the Pope in a broader context, explain the sense of his service and formulate its message, sometimes perceiving the significance of facts differently [14], [28], [50], [46]. Filip Memches's article entitled Papież, który nie dat się lubić (Eng. The Pope who could not be liked) could be interesting to readers looking for strongly polemic accents. The author, proposing a thesis that leftist and liberal circles "impart a tone" to the Pope's criticism and quoting examples, observes, among others, that:

[...] not the benefits of cultural revolution constitute a key event in the history of humanity, but the birth, earthly mission, martyr's death and resurrection of Jesus Christ. And the Church adheres to that. It does not need to follow popular ideological novelties. It is a symbol of opposition, which reminds us of the sense of suffering, in a world where the boundary between good and evil is being blurred so as not to stand in a man's way to "self-realization" [27], [18].

In the researched reports, the role of the element that cements the stories about Benedict XVI, his abdication and - partly - the pontificate, should be played by

${ }^{34}$ The controversial statement that bishop Tadeusz Pieronek gave to the viewers of TVN24, which only the readers of Wirtualna Polska's report could get to know, is noteworthy in this context: "He [Benedict XVI] struggled with much bigger problems than paedophilia. He made sure that people lived according to God's commandments. This is a much more important task than trying to put an end to the paedophile problem, which is and will be present in the world [...] Nitpicking at different matters, which the anti-Church propaganda has been drawing attention to over recent years against Christianity [...], at the moment when the Pope is making a decision of great importance for the Church [...] and the world, is simply abuse" [11]. 
comparisons to John Paul II, which naturally come to mind. However, they were not constructively used, constituting almost exclusively a complementation to opinions about the resigning Pope and emphasizing the aforementioned division into his supporters and critics. The readers of big pictures could therefore learn about the ability of both Popes to maintain their individual style of spiritual and institutional governing, and about the special connection between both pontificates, which allowed Joseph Ratzinger to develop the concept worked out by his predecessor; the concept of a doctrinally traditional Church, which simultaneously reacts to modern challenges. According to critics, on the other hand, both John Paul II and Benedict XVI could not handle the decrease in the Church's significance in people's lives, nor the accumulation of problems within this institution. It is also noteworthy that the problem of choosing completely different ways to end their ministry, which constitutes an interesting contribution to a debate about the unity of spiritual and secular authority that the Pope symbolizes, was almost exclusively taken up only by Church representatives ${ }^{35}$. As should be expected, it was interpreted as valuable evidence of responsibility towards believers and performing the duties of the head of the Church. It seems that readers' opinions could have also been slightly affected by the information that Benedict XVI did not want to speed up the process of John Paul II's canonization. This information was important for Polish recipients and intriguing in terms of being different from the common conviction that the abdicating Pope was committed to strengthening the cult of his predecessor, yet it did not prompt commentaries. An inhibiting role was probably played by the justification of the Holy Father's decision, according to which he wanted all necessary procedures to be maintained, which would not be possible in the circumstances of abdication.

Bearing in mind that the research material is limited, the conclusion arising from the analysis of judgements and assessments on the subject of the abdicating Pope and his pontificate should be treated with great caution. In general, positive opinions are dominant, though they are not significantly more prevalent than criticism - which is most visible in Rzeczposplita's big picture. It seems that the lesser significance of the opinion-forming function which characterizes this report may be justified by its secondary nature - it is comprised of previously published materials and "hot news", which is being discussed by everyone and must be mentioned. Therefore, the big picture reflects the opinion that is currently prevalent in the media and changes (or not) over time; its exposition or stronger persuasiveness decisively depend on the character of the given medium ${ }^{36}$.

\footnotetext{
35 The following exceptions were found in the researched materials: information concerning the comparison of both pontificates and their endings published in Newsweek [3] and the statement of the former Vatican spokesman, Joaquin Navarro-Valls [30].

${ }^{36}$ It concerns the interaction of elements such as the character of the medium (tabloid vs. opinion-forming nature), the dominant perspective of perceiving journalistic tasks (informing vs. interpreting), the sources of materials (agency vs. sent vs. own)
} 
Subjective value is not added to the analysed reports by the third of the previously mentioned themes, which was gradually developed and eventually became dominant, namely the list of the papabile, that is candidates to succeed Benedict XVI. The news concerning this subject, undoubtedly attractive to readers because it presented an opportunity to become emotionally engaged with the events (arousing curiosity, the sense of exceptionality, the tension involved in keeping track of the supposed rivalry), created, above all, the image of a conflict between the supporters of an open and modern church, which responds to present-day challenges, and those in favour of a conservative approach, who safeguard the traditional role of the Pope and clergy. For this reason, the materials which were predominantly presenting the profiles of candidates and the opinions of commentators, apart from biographical details, included similar judgements, sometimes even related phrasing, e.g.:

There is an agreement that it must be a relatively young pope, full of the energy that is necessary to face the challenges and the crisis of the Church, additionally - it would be best if he was from outside of Roman Curia, hence not involved in the disputes or the rivalry of factions, which are broadly described and documented in the materials that were revealed. Many cardinals explicitly implied that the current breakthrough in the Church is a good, historical opportunity to choose someone from outside of Europe [36], [49].

The recurring names (Angelo Sodano, Odilo Scherer, Gianfranco Ravasi, Mauro Piacenza, Christoph Schönborn, Peter Turkson, Timothy Dolan, Sean O'Malley, Luis Antonio Tagle, Marc Quellet) and facts were considered in the context of: evaluating the chances of candidates from outside of Europe, the report of cardinals investigating the functioning of Roman Curia, the disclosure of the contents of Vatican documents and the expectations towards the next head of the Church. The warnings that it is futile to try to predict the winner of the elections were systematically repeated. The subject of Benedict XVI's successor evolved in a certain way - from reporting "the submissions of participants of rivalry" to a diagnosis of serious challenges the new Pope will face. Editors of the studied big pictures realized this general template slightly differently. The diagnosis of difficulties that the Holy Father will have to face appeared on Interia's web page just two days after the abdication had been announced - in an interview with professor Stanisław Obirk [40] $]^{37}$, yet subsequent publications focused on the candidates and desirable traits in Benedict XVI's successor. In an interview given to RMF FM, the columnist Marek Zając briefly presented two possible scenarios of the selection (a Pope from outside of Europe or from Italy) [49], and subsequently an

${ }^{37}$ This material, however, was not included in the tab "Papabile". 
informational text in the radio station's report explained what stands in the way, and what favours the candidates from Italy $[4]^{38}$. The "Italian scenario" returned in materials published during the last days before the inauguration of the conclave, and was supplied with remarks regarding a dispute between conservative and liberal members of the College of Cardinals ${ }^{39}$. The aforementioned template was retained in Rzeczpospolita's big picture, but the content of the publication allows the reader to find out about the speculations and assessments presented in the foreign media [29], an interesting diagnosis of similarities between the problems that trouble the Polish Church and the Churches in Latin America [42], and about conclusions resulting from the comparison of John Paul II's and Benedict XVI's [28] achievements. Wirtualna Polska's report, the most informative in character, included the highest number of news items concerning the changing list of leading candidates, but its editors, as in the case of Interia, made an effort to quickly publish opinion-forming material, which included an analysis of tasks facing the new Pope [34]. Instead of in-depth analyses, the subsequent publications involved only general descriptions of situations [25], brief profiles [24], comparisons of statements, mainly by clergymen, about the most important problems of the activities of the Church and its head, as well as reserved comments [23].

The simplified image of the journalistic story about the abdication of Benedict XVI, which led to the selection of a new Pope, included in analysed reports is comprised of the following elements: the announcement of the decision to abdicate, presented as an unprecedented and surprising event; commentaries concerning this subject, which revealed a clear division into supporters and critics of the institution of the Church and papacy; the earliest speculations concerning the possible successor; information about less significant details and subsequent "events of the day", culminating in the last day of the pontificate; the intensifying speculations as to the possible course and result of the conclave in the context of challenges facing the new Holy Father, which ended with an announcement that Jorge Maria Bergoglia had been chosen. It can therefore be assumed that the chronology of events, according to which the unexpected circumstances of the first day and the unpredictable events of the last, symbolically closing Benedict XVI's pontificate, were the most worthy of interest, turned out to be decisive for the narrative structure.

\footnotetext{
${ }^{38}$ See: „Kto po Benedykcie XVI? Giełda nazwisk ruszyła”, http://www.rmf24.pl/raportwybor-nowego-papieza/rezygnacjapapieza/news-kto-po-benedykcie-xvi-gielda-nazwiskruszyla,nId,931779 [access: 7.03.2013]. This text contained extensive quotes from an interview with Marek Zając.

${ }^{39}$ The theme of candidates' beliefs was discussed in an unusual publication in the report in question - a comparison of "personal questionnaires" of the most important candidates. Apart from biographical data, it contained a section „Poglądy” (eng. "Beliefs”), and in one case (Luis Antono Teagle's) it was not filled.
} 
To conclude the considerations concerning the genealogic aspect of the internet big picture report in the context of papal abdication, it must be noted that journalistic realizations of the genre distinctly proved that it is limited by its nature as a "transitional form". As a compilation of a thematic collection of links and a multimedia article, it combines their advantages (the wealth of panoramic perspectives on the problem and the ability to create an authorial point of view), but exhibits them insufficiently (low degree of organization and coherence of materials, lack of transparency of the overriding aim of the publication). The hypertextual structure of the report constitutes a distant echo of Chinese box composition, yet, from the point of view of the internet user, it is overly chaotic and inconsistent in combining narrative themes. It seems that it would be beneficial both for readers of materials published on the internet and for editors of websites to refrain from publishing big pictures in favour of compiling extensive collections of hyperlinks to appropriately tagged materials, and designing original multimedia articles distinguished by original composition, interesting, interactive and multimedia content and an opinion-forming premise.

In my opinion, the analysis of reports confirms the legitimacy of the above postulate. Each of the four attempts to present the subject of Benedict XVI's abdication in such a form turned out to be more or less defective, which made it difficult to formulate a research approach and accurately relate them to determinants of the two previously mentioned borderline genres. It appears that the still insufficiently developed formula of sharing and editing media content in general information portals and related media institutions determines the deficiency of the examined reports and the vagueness of their final shape.

\section{Works cited}

[1] Abdykacja, czyli okazja do nieśmiesznych żartów, http://wsieci.rp.pl/artykul/979805.html [access: 6.03.2013].

[2] Abp Canterbury wyrazil zrozumienie dla decyzji Benedykta XVI, http://fakty.interia.pl/swiat/ news-abp-canterbury-wyrazil-zrozumieniedla-decyzji-benedykta-xvi,nId,932504 [access: 6.03.2013].

[3] Amerykański,,Newsweek”: Joseph Ratzingerjednym gestem zrobił więcej dlaKościoła niż Karol Wojtyła, http://wiadomosci.wp.pl/kat,135634,title,Amerykanski-Newsweek-Joseph-Ratzingerjednym-gestemzrobil-wiecej-dla-Kosciola-niz-Karol-Wojtyla,wid,15348485,wiadomosc. html?ticaid=1103bc\&_ticrsn=3 [access: 5.03.2013].

[4] Azjatycki Wojtyla czy papież z Czech? „Trzeba być ostrożnym w przewidywaniu faworytów”, http://www.rmf24.pl/raport-wybor-nowego-papieza/wybor-nowego-papieza/news-azjatyckiwojtyla-czy-papiez-z-czech-trzebabyc-ostroznym-w-,nId,941049 [access: 7.03.2013].

[5] Benedykt XVI abdykuje. Pierwsza taka sytuacja od ponad 700 lat, http://wiadomosci.wp.pl/kat,135634,title,Benedykt-XVI-abdykuje-Pierwszataka-sytuacja-od-ponad700-lat,wid,15324745,wiadomosc.html [access: 6.03.2013]. 
[6] Benedykt XVI kontra... wiatr. Najpiękniejsze utarczki, http://www.rmf24.pl/raport-wybornowego-papieza/rezygnacjapapieza/zdjecie,iId,1070963,iAId,75788\#ad-image-0 [access: 5.03.2013].

[7] „Benedykt XVI nie byt postacia charyzmatyczna”, http://fakty.interia.pl/raport-abdykacjapapieza/aktualnosci/news-benedykt-xvi-nie-bylpostacia-charyzmatyczna,nId,939274 [access: 7.03.2013].

[8] Benedykt XVI ustapit. „Teraz jestem po prostu pielgrzymem”, http://www.rmf24.pl/raportwybor-nowego-papieza/rezygnacjapapieza/news-benedykt-xvi-ustapil-teraz-jestem-poprostu-pielgrzymem,nId,937966 [access: 5.03.2013].

[9] Benedykta XVI osiem lat na Tronie Piotrowym, http://www.rmf24.pl/raport-wybor-nowegopapieza/rezygnacjapapieza/news-benedykta-xviosiem-lat-na-tronie-piotrowym,nId,937647 [access: 6.03.2013].

[10] „Bezkrólewie” w Watykanie. Wiele niewiadomych i niejasności, http://fakty.interia.pl/religia/news-bezkrolewie-w-watykanie-wiele-niewiadomych-iniejasnosci,nId,932546 [access: 5.03.2013].

[11] Bp Pieronek: Benedykt XVI zmagat się z o wiele większymi tematami niż pedofilia, wideo, http://wiadomosci.wp.pl/kat,135634,title,Bp-Pieronek-Benedykt-XVI-zmagal-sie-z-owiele-wiekszymi-tematami-nizpedofilia,wid,15326697,wiadomosc.html [access: 6.03.2013].

[12] Bp Polak: Abdykacja papieża Benedykta XVIjestzaskoczeniem, http://fakty.interia.pl/swiat/newsbp-polak-abdykacja-papiezabenedykta-xvi-jest-zaskoczeniem,nId,932492 [access: 6.03.2013].

[13] Byly kamerdyner papieża pracuje w spótdzielni przy watykańskim szpitalu, http://wiadomosci.wp.pl/kat,135634,title,Byly-kamerdyner-papieza-pracuje-w-spoldzielni-przy-watykanskim-szpitalu,wid,15329680,wiadomosc.html [access: 5.03.2013].

[14] Chrabota B., Koniec wieku tytanów, http://www.rp.pl/artykul/61991,981235-Chrabota--Koniec-wieku-tytanow.html [access: 6.03.2013].

[15] Co sadzisz na temat abdykacji Papieża, http://www.rp.pl/artykul/979802.html [access: 5.03.2013].

[16] Ekspert telewizji ARD: Benedykt XVI to postać tragiczna, http://fakty.interia.pl/news-ekspert-telewizji-ard-benedykt-xvi-to-postactragiczna,nId,932507 [access: 5.03.2013].

[17] Giziński J., Tak ustępowali biskupi Rzymu, http://www.rp.pl/artykul/979764.html [access: 6.03.2013].

[18] Graczyk R., Benedykt odchodzi, Bartoś z Obirkiem zostaja, http://fakty.interia.pl/felietony/ graczyk/news-benedykt-odchodzi-bartos-zobirkiem-zostaja,nId,933653 [access: 7.03.2013].

[19] Http://fakty.interia.pl/raport-abdykacja-papieza,nPack,7 [access: 6.03.2013].

[20] Kard. Bertone: osłabienie sil fizycznych, a nie intelektualnych papieża, http://wiadomosci.wp.pl/kat,135634,title,Kard-Bertone-oslabienie-sil-fizycznych-a-nie-intelektualnychpapieza,wid,15326662,wiadomosc.html [access: 6.03.2013].

[21] Kard. Grocholewski: Głównym kryterium będzie zdolność podejmowania trudnych problemów, http://fakty.interia.pl/news-kard-grocholewskiglownym-kryterium-bedzie-zdolnosc-podejmow,nId,933683 [access: 6.03.2013].

[22] Kard. Kazimierz Nycz: papież miat prawo do abdykacji; szanujmy tę decyzję, http://wiadomosci.wp.pl/kat,135634,title,Kard-Kazimierz-Nycz-papiez-mial-prawo-do-abdykacjiszanujmy-te-decyzje,wid,15326330,wiadomosc.html [access: 6.03.2013].

[23] Kard. Nycz o konklawe: nie wykluczam żadnej możliwości, http://wiadomosci.wp.pl/ kat,135634,title,Kard-Nycz-o-konklawe-nie-wykluczamzadnej-mozliwosci,wid,15399575,w iadomosc.html [access: 7.03.2013]. 
[24] Kardynat Timothy Dolan z Nowego Jorku, http://wiadomosci.wp.pl/kat,135634,title,KardynalTimothy-Dolan-z-Nowego-Jorku,wid,15409027,wiadomosc.html [access: 7.03.2013].

[25] Konklawe ma dylemat. Kogo wybierze?, http://wiadomosci.wp.pl/kat,135634,title,Konklawema-dylemat-Kogo-wybierze,wid,15411060,wiadomosc.html [access: 7.03.2013].

[26] Kto po Benedykcie XVI? Giełda nazwisk ruszyła, http://www.rmf24.pl/raport-wybor-nowegopapieza/rezygnacjapapieza/news-kto-pobenedykcie-xvi-gielda-nazwisk-ruszyla,nId,931779 [access: 7.03.2013].

[27] Memches F., Papież, który nie dat się lubić, http://www.rp.pl/artykul/9157,982795-BenedyktXVI----papiez--ktory-nie-dal-sie-lubic.html?p=2 [access: 7.03.2013].

[28] Milcarek P., Poszukiwany Benedykt Plus, http://www.rp.pl/artykul/9157,985166-Poszukiwany-Benedykt-Plus.html [access: 6.03.2013].

[29] Następca Benedykta XVI zdecyduje, jaka drogę obierze Kościót, http://www.rp.pl/artykul/980029.html [access: 7.03.2013].

[30] Navarro-Valls: decyzja Benedykta XVI jest gestem absolutnej odwagi, http://wiadomosci. wp.pl/kat,135634,title,Navarro-Valls-decyzja-Benedykta-XVI-jest-gestem-absolutnejodwagi,wid,15327318,wiadomosc.html [access: 6.03.2013].

[31] Niemiecka prasa: Irytowat protestantów, rozzłościł muzulmanów, http://fakty.interia.pl/ prasa/news-niemiecka-prasa-irytowalprotestantow-rozzloscil-muzulmanow,nId,932541 [access: 6.03.2013].

[32] Ogromne poruszenie na placu Świętego Piotra, http://fakty.interia.pl/raport/abdykacja-papieza/news/ogromne-poruszenie-na-placu-swietego--piotra,1891805,8289 [access: 5.03.2012].

[33] Papież-Niemiec, który „przylgnąt” do Polaków, http://fakty.interia.pl/raport-abdykacja-papieza/opinie/news-papiez-niemiec-ktory-przylgnaldo-polakow,nId,939257 [access: 6.03.2013].

[34] Pawet Załęcki: po abdykacji Benedykta XVI w Watykanie do głosu dojda skrajności, http:// wiadomosci.wp.pl/kat,135634,title,Pawel-Zalecki-poabdykacji-Benedykta-XVI-w-Watykanie-do-glosu-dojda-skrajnosci,wid,15326180,wiadomosc.html [access: 7.03.2013].

[35] Podczas konklawe może dojść do „pojedynku” Włocha i Brazylijczyka, http://www.rmf24. pl/raport-wybor-nowego-papieza/wybor--nowego-papieza/news-podczas-konklawe-mozedojsc-do-pojedynku-wlocha-ibrazylijcz,nId,941384 [access: 5.03.2013].

[36] Podziaty i różne oczekiwania moga utrudnić szybki wybór papieża, http://wiadomosci.wp.pl/kat,135634,title,Podzialy-i-rozne-oczekiwania-moga-utrudnic-szybki-wyborpapieza,wid,15397536,wiadomosc.html [access: 7.03.2013].

[37] Pokoje hotelowe dla uczestników konklawe zostana rozlosowane, http://fakty.interia.pl/raport/abdykacja-papieza/news/pokoje-hotelowedla-uczestnikow-konklawe-zostana-rozlosowane, 1895675,8294 [access: 5.03.2013].

[38] Polski misjonarz biskupem w arktycznej Kanadzie, http://www.rp.pl/artykul/42,981641-Polski-misjonarz-biskupem-w-arktycznej-Kanadzie.html [access: 5.03.2013].

[39] Pożegnanie papieża - minuta po minucie, http://fakty.interia.pl/raport-abdykacja-papieza/ aktualnosci/news-pozegnanie-papieza-minuta-po--minucie,nId,939262 [access: 5.03.2013].

[40] Prof. Obirek: Tragiczny pontyfikat. Benedykt XVI nie radzit sobie z problemami Kościoła, http://fakty.interia.pl/swiat/news-prof-obirektragiczny-pontyfikat-benedykt-xvi-nie-radzilsob,nId,932626 [access: 6.03.2013].

[41] Rzecznik Watykanu: Abdykacja papieża to wydarzenie duchowe, http://fakty.interia.pl/raport-abdykacja-papieza/opinie/news-rzecznikwatykanu-abdykacja-papieza-to-wydarzenieduchowe,nId,935944 [access: 6.03.2013]. 
[42] Szułdrzyński M., Bliższy nam Murzyn niż Francuz, http://www.rp.pl/artykul/9157,985160Blizszy-nam-Murzyn-niz-Francuz.html [access: 7.03.2013].

[43] Trzy miesiace temu papież przeszedt zabieg. Wszystko odbyło się w tajemnicy, http://www. rmf24.pl/raport-wybor-nowego-papieza/rezygnacjapapieza/news-trzy-miesiace-temu-papiez-przeszedl-zabieg-wszystko-odbylos,nId,931889 [access: 6.03.2013].

[44] Watykańska liga mistrzów. Z której grupy wyjdzie papiez, http://www.rmf24.pl/raportwybor-nowego-papieza/wybor-nowego-papieza/newswatykanska-liga-mistrzow-z-ktorejgrupy-wyjdzie-papiez,nId,941605 [access: 5.03.2013].

[45] Wielkie oczekiwanie na Placu Świętego Piotra. Papież o 17 odleci do Castel Gandolfo, http:// www.rmf24.pl/raport-wybor-nowego-papieza/relacje/audio,aId,1072108 [access: 5.03.2013].

[46] Wiślicki T., Papież spraw najważniejszych, http://www.rp.pl/artykul/981753.html?p=1 [access: 6.03.2013].

[47] Włochy: „Haniebna manipulacja wobec kardynała Dziwisza. Horror”, video, http://www. tv.rp.pl/artykul/980004.html [access: 7.03.2013].

[48] Wysocka S., Benedykt XVI przejdzie do historii. Pierwszy papież-emeryt, http://fakty.interia. $\mathrm{pl} /$ raport-abdykacja-papieza/aktualnosci/newsbenedykt-xvi-przejdzie-do-historii-pierwszypapiez-emeryt,nId,939191 [access: 5.03.2013].

[49] Zają: Na konklawe kardynatowie moga szukać młodszego kandydata, http://www.rmf24.pl/ raport-wybor-nowego-papieza/rezygnacjapapieza/news-zajac-na-konklawe-kardynalowiemoga-szukac-mlodszegokandyda,nId,931743 [access: 7.03.2013].

[50] Zdort D., Korekta Benedykta, http://www.rp.pl/artykul/61991,981218-Korekta-Benedykta. html [access: 6.03.2013].

\section{Bibliography}

Chyliński M., Russ-Mohl S., „Dziennikarstwo”, Grupa Wydawnicza Polskapresse, Warsaw 2007, pp. 120-131.

Olszański L., „Dziennikarstwo internetowe”, Wydawnictwa Akademickie i Profesjonalne, Warsaw 2006.

Olszański L., „Media i dziennikarstwo internetowe”, Wydawnictwo Poltext, Warsaw 2012.

Palczewski M., „Ontologiczne modele newsa. Zarys problematyki”, Studia Medioznawcze 2010, No. 2, pp. $145-148$.

Trzebiński J., „Narracyjne konstruowanie rzeczywistości”, in: „Narracja jako sposób rozumienia świata”, ed. J. Trzebiński, Gdańskie Wydawnictwo Psychologiczne, Gdansk 2002, pp. 17-42. http://tematy.newsweek.pl/temat/abdykacja_benedykt [access: 5.03.2013]. http://tvp.info/informacje/raporty/abdykacja-benedykta-xvi [access: 5.03.2013]. http://wiadomosci.onet.pl/tagi/papiez-benedykt-xvi-abdykuje,73699,tag.html [access: 5.03.2013]. 
Monika Worsowicz

\section{Non habemus papam - the Abdication of Benedict XVI as Depicted in Polish Realisations of the Big Picture Report (Genealogical Contexts)}

\section{(Summary)}

This article is devoted to outlining characteristics of the big picture report on the basis of publications focusing on the abdication of Pope Benedict XVI. The analysis of this content enables us to determine how the genre functions as a form of media communication relying on exchange of news, and how it exploits the specificity of the internet as a means of transmission. An attempt is made to show how this form of journalistic expression may evolve and to describe its usefulness from the point of view of the audience.

Keywords: abdication of Benedict XVI, Polish big picture report, Internet. 